\title{
Introduction and Validation of Ethics Practices Scale (EPS) and its Application in
} Pakistani Higher Education

\author{
* Dr. Syed Zubair Haider, Assistant Professor (Corresponding Author) \\ ** Dr. Uzma Munawar, Assistant Professor \\ *** Dr. Rafaquat Ali, Assistant Professor
}

\begin{abstract}
The ethics among educators determine the educative standards of the institution. To clarify the present state, this paper attempted to gain a better understanding of the ethics practices of university faculty in Pakistan. This question was explored in this study by collecting data from 1200 Pakistani Higher Education students through questionnaires, administered at four public sector universities of Pakistan. Multiple analyses, CFA, EFA, correlation, and paired sample t-test were calculated to measure perspectives. Four factors, teachers-students relationship (TSR), teachers conduct towards the community (TCC), teachers and teaching profession (TTP), and teachers' relation to colleagues and management (TCM) emerged as a result of EFA and CFA. The findings showed that the scale is a valid and reliable tool that can be used in Pakistani Higher Education. The study also highlights the need of giving specific attention to maintaining high standards of moral principles not only in higher education institutions (HEIs) but also in the society as well as a code of professional ethics that should also be made available to the faculty of HEIs to abide by them.
\end{abstract}

Keywords: Ethics, Practices, Higher Education, Teachers, Society

Introduction

Ethics is a branch of moral philosophy that includes definition and recommendation of the right and wrong perceptions. Ethics is a logical discipline that attempts to make goals and standards by scrutinizing the good practices and intends to support people, organizations and specialists decide by empowering them to separate right from wrong (Vaughn, 2015). Curtis (2006) define ethics as truth, fairness, honesty, right, justice, and a code of moral conduct. In decision-making processes, ethics play a key role to define normative social ideals that are grounded in the cultural values of a particular society (Campbell, 2000) and are important in guiding all decisions and determining courses of correct action (Bishop, 2013). Ethics is a lifelong process rather than an event and it is essential for maintaining excellence in the individual's conscience (Somerville, 2000). Professional ethics are required in every profession to direct the employees and maintain the existence of the profession. Professional ethics ensure the description of professional responsibilities in such an ethical manner that by practicing them some employees will be treated according to their high expectations.

In the current era, people are more aware of ethical principles and practices than ever before. To provide quality of cultural and social life to a nation, all its professions must abide by particular codes of ethics. The general standards featured in this proficient code of ethics incorporate usefulness and nonmaleficence, devotion and obligation, honesty, equity, and regard for individuals' privileges and pride (American Psychological Association, 2017). So, the highest priority should give to develop enthusiastic and responsible, ethically sound professionals for integrating the expectations of a society. The hypothetical model that underscores the test things originates from a by and large acknowledged rundown of ethics talked about in moral theory and specific to undergrad conduct (Plante \& Plante, 2016). In providing morality (morally appropriate attitude) and a favorable attitude towards practicing ethical values, many professional organizations have adopted ethical codes

\footnotetext{
* Department of Educational Training, the Islamia University of Bahawalpur, Punjab, Pakistan

Email: zubairiub@hotmail.com

** Department of Education, Govt. Sadiq College Women University, Bahawalpur, Punjab, Pakistan

Email: druzmamunawar@gmail.com

*** Department of Education, The Islamia University of Bahawalpur, Bahawalnagar Campus, Pakistan

Email: rafaquatiub@yahoo.com
} 
relevant to their field of exertion (Freeman, 2000). These codes are required to fill the gap between an individual's morality and practical standards for molding human personalities into a creative, trustworthy, courageous, honest, and appreciative person. Like many other professions, teaching is also a multifaceted process, required special human traits. It is believed that teachers should be an example of morals.

Teacher's ethics are particularly significant in settings requiring continuous and everyday common decision making related to some significant results (Plante \& McCreadie, 2019). Teaching ethics is a set of beliefs accepted by teachers regarding their relationships with colleagues, students, employees, and parents, all of them are moral negotiators in a life of a teacher (Banks, 2003). They are moral norms and behavioral standards, which teachers, administrators, and educational employees must observe and apply in academic situations. Therefore, teachers' ethical practices are more important to social interaction and academic integrity. Particularly in higher education, teachers need more awareness about teaching ethics practices to show an essential zeal in providing standard-based quality education (Zheng \& Hui, 2005).

In research literature, a significant debate on teaching ethics practices has been performed since the mid-1980s. The studies proposed that teachers have no sufficient awareness regarding the ethical impacts of their actions (Husu \& Tirri, 2001; Thornberg, 2008). Teaching ethics regarding different institutional issues encountered by teachers are very difficult to locate. Freeman (2000) argued that ethically sound teachers demonstrate their commitment to the teaching profession, students, and society. For effective, ethical decisions, teachers are required to be good moral agents and representatives (Campbell, 2003). There is a strong need of HEIs to revisit their ethical standards for the creation of a distinctive learning environment, where students could learn how to respect others, how to become ethical citizens, how to be autonomous and how to live life in a prejudice-free manner (Couch \& Dodd, 2005). By adopting the code of ethics, teachers will not only get benefits in teaching, but also pave the way to reduce students' and parents' criticism in educational matters (King \& King, 2008).

In an educational environment, we often hear about two types of ethical practices. Good or positive ethics practices related to the teaching-learning process and bad or negative practice, which teachers should eradicate from their professional behavior (Cuza \& Alecsandri, 2015). Universities are responsible for endorsing moral standards and principles amongst their learners to help them in their individual, social and vocational endeavors. In university education, ethics require a higher degree of accountability with the privilege of teaching and guiding students in an effective way (Smith \& Zhang, 2009). University instructions play a significant role within and outside the classroom to evaluate contradictions between ethical theories and practices (Fenwick, 2005). The proficient, ethical, enthusiastic, confident, innovative, and emotionally stable teachers are required at higher levels.

Universities develop their codes of ethics for promoting best ethics practices. This includes teachers' performance as moral mentors, unbiased dealings with all students and properly establishing teacher and student relationships (Margalef \& Pareja Roblin, 2016). Hence, ethical principles lie at the core of the teaching profession. A clear vision, collective understanding, and establishment of an evident set of ethical doctrine can be supportive in professional judgment and accomplishment of the academic achievements of teachers. At the tertiary level, a clear set of goals, a favorable attitude towards learners, and love for the profession is the need of the time to practice ethical considerations effectively (Haider \& Dilshad, 2015). Apart from the mention above theoretical discussions, this study is conducted to establish and validate an ethics practice scale and measure the ethics practices of university faculty. Through analyzing teachers' practices of ethics, this research paper strives to provide some meaningful shreds of evidence for developing a positive ethical attitude towards their profession. This area has not previously been actively explored, despite numerous research studies that have focused on ethical dilemmas.

\section{Material \& Method}

The problem under investigation focuses on the present situation (prevailing or current condition) and keeping in view the nature of the study, the descriptive research design was found appropriate (Haider \& Hussain, 2014; Haider \& Qureshi, 2016). Among different designs, the survey was considered to be the most suitable to extract reliable results. It comprises managing a meeting in an individual or by telephone or conducting a survey in an individual, by telephone, or employing mail (Fraenkel \& 
Wallen, 2009). However, these characteristics are not limited to quantitative research design, they can be used in qualitative research design as well

\section{Scale Development}

To investigate the ethics practices (Including both ethical and non-ethical practices) of university teachers, it was necessary to develop and validate a research tool. The tool development and validation were based on measuring the ethics practices of university teachers in Pakistan regarding students' perspectives. An empirical approach was brought into consideration regarding the ethics practices of university teachers (Kline, 2005; Worthington \& Whittaker, 2006; Cohen \& Swerdlik, 2010). Scale Development was performed in four phases.

\section{Phase 1}

\section{Focus Group Discussions (FGDs) with University Students}

Lack of existing literature on ethics practices of university teachers led the researcher to the decision of establishing FGDs (Krueger, 1988). An interactive process was required to get first-hand information. For conducting a focus group discussion, the following methodology was used. Based on the literature review a "topic guide" comprising 20 questions was prepared. For example, what comes in your mind when you think about teachers' moral obligations? What are your perceptions regarding teachers' ethical practices? Report any event that you remember concerning biased dealings with students? Under each question probing questions were generated to get a breath of responses.

Total 97 questions, based on four broad categories were explored including TSR, TCC, TTP, and TCM by end of last FDGs. For sample selection age, gender, department, academic qualification, designation, the experience was also taken into consideration for creating meaningful differences in responses. For the selection of participants, the random sampling technique was used. Two FGDs were conducted with females (one for female teachers and one for female students of social sciences) and two with males (one for university teachers and one for university students of physical sciences). The number of participants in FGDs varied from 18-20 participants in each. For conducting FGDs in a structured format non-directive approach was used. For getting similar responses, all FGDs were conducted constantly. Verbal responses were written and audio-recorded. Five MPhil education researchers assisted to note down responses. Every FGD took 2 to 3 hours for its completion.

\section{Phase 2}

\section{Items Generation}

After recording the verbatim, the next step was item generation for which content analysis was completed. Initially, 97 items were generated. Only those items were retained which were showing overlapping between both types of groups. Generated items shared university teachers and students' opinions related to teacher's emotional stability in fronting innovative encounters of life, their persistence to solve moral problems of academia, efficiency in practicing Islamic values, cooperation with students in apprehending their abilities, evaluation of students through reliable sources, likability for maintaining positive social interaction, etc. Content analysis of FGDs with university students revealed that teaching faculty is not serious to improve their familiarity regarding ethical practices. That is why; these questions were also made a part of the scale for delineating better analysis based on students' beliefs regarding ethics practices.

\section{Phase 3}

\section{Committee Approaches}

Six Ph.D. researchers ( 2 men, 4 women) of the $4^{\text {th }}$ semester ( 3 Psychology, 3 Education) were engaged in the selection of items from the item pool (Kline, 2005; Worthington \& Whittaker, 2006; Cohen \& Swerdlik, 2010). Initially, 76 items were recommended, which were reduced to 39 items by removing overlapped and double-barrelled items in another committee meeting involved two lecturers from the education department and one from the psychology department. Finally, a basic structure for gauging ethics practices of university faculty was developed and was put in the corresponding phase for exploratory factor analysis.

\section{Phase 4}

Pretesting

In this phase, after finalizing items, EFA was run to explore the scale composition. After performing EFA, four factors, TSR, TCC, TTP, and TCM were extracted in this study. 


\section{Study Participants}

The sample of the study was 1200 students from four public universities [The Islamia University of Bahawalpur (IUB), University of Punjab (PU), Allama Iqbal Open University (AIOU) and University of Karachi (UOK)] with 05 departments of physical sciences such as Mathematics, Statistics, Physics, Biology and Chemistry and 05 departments of social sciences including Education, Arabic, History, Pak-Studies, and Psychology from each university. Purposive sampling technique was applied to choose the true representation from the target population. The required arrangements were made to draw the true representative sample. According to the study requirement; responses were collected from 30 students (15 male and 15 female) from each department.

\section{Procedure}

We collected the required data from students of four selected Universities. For data collection, the consent and willingness in written were obtained from respondents. They were requested to carefully follow the instructions for filling the questionnaire. Absolute secrecy and anonymity were assured to the respondents. At the end of the questionnaire, respondents' suggestions and comments regarding questions were also requested. Respondents did not report any complicatedness in understanding and answering the questions and took only 10 minutes to complete it. SPSS $22^{\text {nd }}$ was used to analyze data.

\section{Factor Analysis}

For factor extraction and homogenous item groupings (Worthington \& Whittaker, 2006) broadly employed empirical measure of scale development EFA was used. A PCA followed by Varimax rotation was used to extract uncorrelated items of the research instrument. Kaiser-Meyers-Olkin measure of sampling adequacy (KMO) generated a value of .896, demonstrating respondents to items ratio adequate for running EFA. Bartlett's Test of Sphericity (Bartlett, 1954) was significant ( $\mathrm{p}<$ .000) manifesting the adequate distribution of data that permit an estimation of the possible factor structure. The results of EFA demonstrate that the 04 factor solution was identified with Eigen-value greater than 1.0 and accounted for more than $59 \%$ of the common variance.

Finally, in all factors, only those items were retained that have .40 (Walker \& Maddan, 2008) or more factor loading, cross-loading less than .35 and simultaneously, not loaded on two or more than two factors. In the final scale, three items, 8, 13, and 26 could not fulfil the minimum standard of .40 for retention, therefore, provide sufficient evidence for excluding these items. Further confirmatory factor analysis (CFA) of the questionnaire showed a substantially high relationship between the error variances of questions 08,13 , and 26. Modification indices pointed out that the elimination of these items could better the goodness of fit. The CFA results for remaining questions manifested that the remaining factors CFA model fitted the data very well (Chi-square goodness of fit $=7.19, \mathrm{df}=34, \mathrm{p}=0.19 ; \mathrm{CFI}=0.90 ; \mathrm{NNFI}=0.84 ; \mathrm{RMSEA}=0.03 ; \mathrm{IFI}=0.91 ; \mathrm{RFI}=0.86 ; \mathrm{NFI}=$ 0.89) (See Table 1).

Table 1. EFA Factor loadings of 36-items Ethics Practices Scale $(\mathbf{N}=1200)$

\begin{tabular}{|c|c|c|c|c|}
\hline \multirow[b]{2}{*}{ Teacher } & \multicolumn{4}{|c|}{ Factors Loading } \\
\hline & TSR & TCC & TTP & TCM \\
\hline 7. Is caring to give equal chances for both groups. & 0.87 & & & \\
\hline 6. Evaluate students in biased manner & 0.71 & & & \\
\hline 3. Keeps students' personal information confidential. & 0.65 & & & \\
\hline 10. Sexually harass the students & 0.65 & & & \\
\hline 2. Is willing to make students ethical. & 0.62 & & & \\
\hline 12. It is supportive for learners in recognizing their potentials. & 0.61 & & & \\
\hline 11. Develops honesty among learners. & 0.58 & & & \\
\hline 9. Efficiently endorses work habits among students. & 0.56 & & & \\
\hline 1. Politely behaves with students. & 0.51 & & & \\
\hline 17. Is uncaring in keeping high values of moral actions. & & 0.81 & & \\
\hline 14. Is sovereign in giving views on various issues. & & 0.71 & & \\
\hline 30. Acts clearly to fulfil different ethical canons. & & 0.69 & & \\
\hline 18. Try to endorse democratic standards. & & 0.68 & & \\
\hline
\end{tabular}


20. Is emotionally mature to handle new encounters of life. 0.64

15. Displays a careless attitude in establishing harmony in society.

0.62

5. Is determined to produce positive behaviour for life.

0.54

16. Maintain positive collaboration.

0.54

19. Take a keen interest in enhancing professional growth.

29. Is enthusiastic to better educational quality of the institution.

0.76

22. Has an ability to utilize instructional material properly.

0.74

21. Is enthusiastic towards own learning.

25. Is dutiful in performing his/her professional duties.

23. Is vigilant in evading gender favoritism.

27. Works effectively for research-based instructional plans

4. Follow rules to attain teaching learning goals in time.

24. It is careless to increase information regarding

31. Give proper time to his / her profession.

28. Is competent in performing Islamic morals.

33. Follows directions of school administration.

32. Give honor to his/her fellows.

34. Develops a pleasant relationship with his/her fellows.

35. Bear constructive criticism tolerantly on instructional

36. Work hard for the improvement of the institution.

37. Appreciates ethical discussions with colleagues.

0.54

39. Is willing to solve moral issues of the institution.

0.42

38. It helps in creating a conducive learning environment.

0.40

Total Variance Explained \% (59.14)

Finally extracted items were conferred to 4 Ph.D. scholars in Education to give names to 4 factors on account of substance to ensure face and content validity. They were requested to propose the most suitable title for each variable. Thirty-six (36) items were finally retained and after their judgments, dimension (1) was named as "Teacher-Student Relationship" (TSR) 09 items (7, 6, 3, 10, $2,12,11,9,1)$ referred to know the teachers' behaviors with their students, develop morality, provision of equal opportunities, promote wok habit among students, etc. Dimension (2) was termed as "Teachers' Conduct towards Community" (TCC) 08 items $(17,14,30,18,20,15,5,16)$ measure teachers' social interaction, securing peace in society, maintaining standards in ethical practices, etc.

Dimension (3) was named as "Teachers and Teaching Profession" (TTP) 11 items (19, 29, 22, $21,25,23,27,4,24,31,28)$ developed for knowing personal interest for enhancing professional competencies, awareness of using educational resources, efficiency in practicing Islamic moral values, etc. Dimension (4) was named as "Teachers relation to Colleagues, Management and Institution" (TCM) 08 items $(33,32,34,35,36,37,39,38)$ referred to teacher's aptitude in holding upright, pleasant and sincere terms with their fellows and administration, persistence in resolving ethical conflicts and patience to accept criticism on institutional matters. At Last, an Ethics Practices Scale (EPS) with 36 items having scoring categories gauged on a four-point scale ranging from Strongly Disagree (1) to Strongly Agree (4) was developed. In the scale, 05 questions were reverse scoring (items $6,10,15,17$, and 24). A high score on the scale represented more ethical than the teacher.

\section{Psychometric Properties}

For reliability analysis, Cronbach's alphas were computed. The resulting Cronbach's alpha coefficient for EPS was found to be .89 (Thompson, 2003) and for sub-factors, TSR $(\alpha=0.86)$, TCC $(\alpha=0.84)$, $\operatorname{TTP}(\alpha=0.79)$ and TCM $(\alpha=0.80)$ respectively ranging from moderate to high (Bowling, 2014). 


\section{Results}

The present study was designed to discover the ethics practices of university teachers in Pakistan. The results deal with the analysis and interpretation in the light of study objectives.

Table 2. Correlation coefficient among Dimensions of Ethics Practice Scale

\begin{tabular}{lllllll}
\hline & Mean & SD & 1 & 2 & 3 & 4 \\
\hline 1. Teacher-Student Relationship & 30.51 & 1.15 & - & & & \\
2. Teachers' Conduct towards Community & 22.37 & 1.17 & .073 & - & & \\
3. Teachers and Teaching Profession & 33.02 & 1.39 & $.395^{*}$ & $.204^{*}$ & - & \\
4. Teachers relation to Colleagues, & 21.99 & 1.36 & .115 & $.686^{* *}$ & $.247^{* *}$ & - \\
Management and Institution & & & & & & \\
\hline
\end{tabular}

$* * \mathrm{p}<0.01, * \mathrm{p}<0.05$

The Spearman correlations coefficients between ethics practices are shown in (Table 3). A moderate statistical correlation was observed between teacher-student relationship $r=.395, p<.05$, and teacher and teaching profession. Whilst teacher conduct towards community is weakly associated with teachers and teaching profession $r=.204, p<.01$ and highly correlated with teacher relation to colleagues, management and institution $r=.686, p<.01$. Similarly, the teacher and the teaching profession is also highly associated with teachers' relation to colleagues, management and institution $r=.247, p<.01$. The perspectives of students on four factors were analyzed by adding the perceptions on questions under each dimension and calculating the percentage of agreement and disagreement of perspectives within each dimension. Responses from 1-2 points (strongly disagree and disagree) were merged to identify disagreement subscale and responses from 3-4 points (strongly agree and agree) were considered as an agreement perception. The difference of significance level among agree and disagree sets of perceptions was calculated through paired sample t-tests, mean and standard deviation.

\section{Table 3. Students' Perspectives on Teacher-Student Relationship}

\begin{tabular}{lll}
\hline Teacher & Disagree (\%) & Agree (\%) \\
\hline 1. Politely behaves with students. & 29.6 & 70.4 \\
2. Is willing to make students ethical. & 37.6 & 62.4 \\
3. Keeps students' personal information confidential. & 38.5 & 61.5 \\
6. Evaluate students in a biased manner & 18.6 & 81.4 \\
7. It is caring to give equal chances for both groups. & 37.9 & 62.1 \\
9. Efficiently endorses work habits among students. & 19.1 & 80.9 \\
10. Sexually harass the students & 27.3 & 72.7 \\
11. Develops honesty among learners. & 36.3 & 63.7 \\
12. It is supportive for learners in recognizing their potentials. & 18.1 & 81.9 \\
Overall response (Mean \& SD) & $29.22(2.94)$ & $70.77(2.94)$ \\
Paired Sample t-test & $\mathrm{t}(8)=-7.05$ & P-value $=.000$ \\
\hline
\end{tabular}

Teacher-student relationship

It is evident from (Table 3) that given more than $70 \%$ of students, the teachers exhibit specialized attitude, extend empathy and support their learners. They provide a supportive learning environment for learners. Treat all learners in a neutral and humanistic way. Their prime objective is to identify learners' liking and always be helpful to students. They remain secret students' issues and information, always try their best to improve students' continuous development. Always encourage students to enhance their expertise. Likewise, most of the students agreed that their teachers assess their performance by using several dependable ways and try to instill maximum ethical and communal values in them. The overall mean and standard deviation for agreeing responses $(M=70.77, S D=$ 2.94) represents that students usually have good and optimistic views about teacher student's relationship, whilst statistically significant difference was observed between agree and disagree sets of responses in favor of agree side $(t(8)=-7.05, p=.000)$. 
Table 4. Students' Perspectives on Teachers' Conduct towards Community

\begin{tabular}{lll}
\hline Teacher & Disagree (\%) & Agree (\%) \\
\hline 5. Is determined to produce positive behavior for life. & 27.7 & 72.3 \\
14. Is sovereign in giving views on various issues. & 41 & 59 \\
$\begin{array}{l}\text { 15. Displays a careless attitude in establishing harmony } \\
\text { society. }\end{array}$ & 31.6 & 68.4 \\
16. Maintain positive collaboration. & 49.4 & 50.6 \\
17. Is uncaring in keeping high values of moral actions. & 21.5 & 78.5 \\
18. Try to endorse democratic standards. & 47.8 & 52.2 \\
20. Is emotionally mature to handle new encounters of life. & 10.6 & 89.4 \\
30. Acts clearly to fulfill different ethical canons. & 39.2 & 60.8 \\
Overall response (Mean \& SD) & $31.87(13.53)$ & $68.12(13.53)$ \\
Paired Sample t-test & $\mathrm{t}(8)=-4.01$ & P-value $=.004$ \\
\hline
\end{tabular}

Teachers' conduct towards community

It is evident from Table 4 that the majority of teachers (68\%) perform their best to develop a respectful, suitable, and acceptable attitudes towards society. They tried their best to provide students with quality education and also play their positive role to establish an efficient and better teachinglearning environment. Teachers also try to develop such a supportive atmosphere in which critical thinking skills of all students are polished and enables students to solve their learning difficulties. However, $32 \%$ of teachers reported causal behavior in maintaining moral standards, moreover, they do not give proper attention to this important issue of morality, deviate from their responsibilities to establish peace in society. The overall mean and standard deviation for agreeing on responses $(M=$ 68.12, $S D=13.53$ ) describes that students usually have positive and encouraging reflections considering teachers' conduct towards community whilst statistically significant difference was observed between agree and disagree sets of responses in favor of agreeing on the side $(t(8)=-4.01, p$ $=.004)$.

Table 5. Students' Perspectives on Teachers and Teaching Profession

\begin{tabular}{lll}
\hline Teacher & Disagree (\%) & Agree (\%) \\
\hline 4. Follow rules to attain teaching learning goals in time. & 26.9 & 74.1 \\
19. Take a keen interest in enhancing professional growth. & 37.2 & 62.8 \\
21. Is enthusiastic towards own learning. & 37.5 & 63.5 \\
22. Has an ability to utilize instructional material properly. & 37.6 & 62.4 \\
23. Is vigilant in evading gender favoritism. & 42.8 & 59.4 \\
24. It is careless to increase information regarding professional & 56.6 & 43.4 \\
values. & 22.8 & 77.2 \\
25. Is dutiful in performing his/her professional duties. & 40.2 & 62.8 \\
27. Works effectively for research-based instructional plans & 39.6 & 64.4 \\
28. Is competent in performing Islamic morals. & 25.9 & 79 \\
29. Is enthusiastic to better educational quality of an institution. & 38.3 & 63.7 \\
31. Give proper time to his / her profession. & $35.22(12.29)$ & $64.79(9.72)$ \\
Overall response (Mean \& SD) & $\mathrm{t}(10)=-4.58$ & P-value =.001 \\
Paired Sample t-test & & \\
\hline
\end{tabular}

Teachers and teaching profession

According to Table 5, most of the teachers (65\%) believed that they fulfill their responsibilities honestly and effectively. They consider teaching as a vocation and love teachinglearning process, work hard to fortify their skills. They are vigilant to fulfill their occupational duties, establish an atmosphere of love and care, provide their unconditional support to their learners which helps them to improve the academic achievement of their students. Furthermore, the continuously evaluate their learning to obtain educational objectives timely. They are very curious to enhance their 
knowledge, improve their skills, and frequently obey Islamic laws and values. However, $35 \%$ of teachers are found less effective and inconsiderate in cultivating a positive attitude, enhancing understanding regarding occupational morality. The overall mean and standard deviation for agreeing responses $(M=64.7, S D=9.72)$ shows that students normally have optimistic thinking considering teachers and teaching profession whilst statistically significant difference was observed between agree and disagree sets of responses in favor of agree on side $(t(10)=-4.58, p=.001)$.

Table 6. Students' Perspectives on Teachers' relation to Colleagues, Management and Institution

\begin{tabular}{lll}
\hline Teachers & Disagree (\%) & Agree (\%) \\
\hline 32. Give honor to his/her fellows. & 35.7 & 64.3 \\
33. Follows directions of school administration. & 33.8 & 66.2 \\
34. Develops a pleasant relationship with his/her fellows. & 34.1 & 65.8 \\
35. Bear constructive criticism tolerantly on instructional matters. & 38.6 & 61.4 \\
36. Work hard for the improvement of an institution. & 35.9 & 64.1 \\
37. Appreciates ethical discussions with colleagues. & 35.7 & 64.3 \\
38. It helps in creating a conducive learning environment. & 35.3 & 64.7 \\
39. Is willing to solve moral issues of the institution. & 34.1 & 65.9 \\
Overall response (Mean \& SD) & $35.35(1.65)$ & $64.62(1.64)$ \\
Paired Sample t-test & $\mathrm{t}(6)=-23.42$ & P-value $=.000$ \\
\hline
\end{tabular}

Teachers' relation to colleagues, management and institution

Table 6 clearly explains that given (64\%) teachers, they have a very respectable and congenial working relationships with their fellows and administration. They usually discuss the matters of moral issues faced within the institution with their colleagues. They normally provide help to all students regarding the importance of knowledge, need of ethics in daily discussion and routine matters, guide them about new advancements in the global world, and our role as a learner to work positively for our society and institution. The majority of teachers have a view that they obey the institutional rules, fulfill their responsibilities, and obey the rules passed by management for a better teaching-learning process. Furthermore, they accept constructive feedback patiently and positively in educational matters. They work professionally, work hard to solve institutional moral issues, deal with their students, colleagues, and administration politely, build relations on a professional basis, and work for the improvement of institutional morality. The overall mean and standard deviation for agreeing responses $(M=64.62, S D=1.64)$ depicts that students mostly have constructive insights about teachers' working relation to colleagues, administration and institution whilst statistically significant difference was observed between agree and disagree sets of responses in favor of agree side $(t(6)=-23.42, p=.000)$.

\section{Discussion}

Teachers are responsible for molding young generations, possess qualities to grasp the teachinglearning process, and have a major influence on the entire organization. Aghenta (1991) argued that the impact of teachers is very crucial to change the underdone substance (especially students) in the final form. Therefore, it is an important obligation of higher education to train a cohort of university teachers with perfect mastery, supercilious ethical practices and provide guidance to fulfill their duties more effectively. Many unfair practices and events are continuously reported at workplaces daily. Subsequently, a sizeable number of persons have lost confidence and showed their dire concern on the teaching quality and professionalism of the teachers of HEIs to guide the young people to perform ethically ((Frisque, Lin, \& Kolb, 2004).

According to Pellitier and Bligh (2006), people moral reasoning has increased universally in all areas of human life. Therefore, higher education institutions must analyze the situation and play their role in the conflict management necessary for the ethical environment of the institution (Fenwick, 2005). The study results considering teachers and students revealed that teachers are considered answerable and mentor for the overall growth and development of learners and the essential liability of instructor is the character formation of their students. This notion was further 
strengthened by (Kelley, Agle, \& DeMott, 2005; Weber, 2006) and they believed that the responsibility comes on HEIs for the formation of learners' ethical attitude.

The study results revealed that teachers give respect to students' confidentiality, hide their personal information, do not discuss it with other students or even their fellows to save students from any harm. They provide learners full freedom to display their potentials and work hard to enhance students' capabilities and try to boost the teaching-learning environment. They treat their colleagues with respect and develop good working and heartfelt approachable relations with them to make the teaching-learning process more enjoyable. The same results were drawn by Murray, Gillese, Lennon, Mercer, and Robinson (1996) expressed that most of the teachers of HEIs deals with the personal issues of their students with confidentiality. They usually believed on good teacher-student relationship that why they deal their students just like lawyer deals his clients or doctor deals his patients because they look fully aware of the importance of secrecy and have well understanding that defilement of secrecy may result in cynicism in instructors and little enthusiasm towards the academic performance of their students. They are also looking very helpful in taking essential steps for the wellbeing of learners.

Many studies have revealed that teacher-colleagues relation strongly affect the teachinglearning process and students' performance (Hertzog, Pensavelle, \& Lemlech, 2000). For the improvement of their professional qualities and skills, it is inevitable to flourish a culture of ideas sharing, helping academically weak colleagues, guiding in the attainment of educational objectives, and assisting in improving professional practices. The study findings revealed that teachers' role is very important in inculcating honesty and veracity among learners. Campbell (2003) also favored this idea that teachers should be a symbol of ethicality for their students as well as an ethical educator. $\mathrm{He}$ should develop necessary ethical standards in his learners that strive to sustain in specialized practices and showed employing their behaviors, commitment, action, and promise. Glegg (2003) depicted that teachers are regarded as a symbol of morality and they have a great responsibility of shaping students' character and work as an ethical agent of the society.

The study results showed that the teachers are reliable in assessing their learners. They tried their best to treat every learner fairly, with love, sympathy, and by utilizing justified comprehensive evaluation procedures. This finding was reinforced by Lovat \& McLeod (2006) they argued that a professional teacher uses fair and justified procedures to evaluate his students. The findings also manifest that teachers of HEIs try their best to inculcate honesty among students. Couch and Dodd (2005) also supported these results that teachers of HEIs should boost and reassure students to involve in community services and academic activities. Moreover, the findings explored that most of the students idealize their teachers and perceived them as role models.

Many researchers argued that teaching is not only the acquiring of knowledge and learning of specific abilities and skills but it is more than that involving societal well-being, fairness in dealings, and soundness of character in both professional and personal endeavors (Brok, 2001; Shuell, 1996). Therefore, a teacher should be effective and have a strong effect on their students' personality, as they mainly copy their teachers' personality and behaviors. The study findings revealed that teachers of HEIs are much aware of the importance of professional ethics and they have the inspiration to increase their awareness and knowledge regarding ethical standards and their moral actions. Barrett, Headley, Stovall, and Witte (2006) also favored this finding and emphasize that teachers should be more conversant regarding underlying moral phenomena of the teaching learning process. Furthermore, they are well aware of the knowledge and importance of ethical values try their best to practice these professional standards and obligations in an expected ethical attitude.

\section{Conclusion}

The growing dialogue in the educational literature regarding the ethical practices in the teaching profession as well as the involvement of ethics training in the ethical decision-making of future professionals. This research study explored the ethics practices of university teachers. A specialized teacher is who accomplishes his commitments professionally and tries his best to promote educational standards. The key findings revealed that the majority of teachers $(94 \%)$ had constructive insights regarding their moral actions and almost more than 70\% HEIs students conveyed optimistic responses regarding moral practices of their teachers. This study provides the groundwork for a broad assessment and debate regarding the state of professional ethics among HEIs teachers. 


\section{Actions Implications}

This situation demands serious deliberations of teachers to understand their roles and responsibilities. A certain list of professional ethics may be provided by each university to strictly abide by university teachers. Teachers should attend seminars and conferences to enhance their professional competencies. They should focus on transmitting Islamic ideology to the students, delivering the basic knowledge of Islamic values, norms, and rituals. In this regard, students may be presented with practical examples from the Holy life of our beloved Prophet Hazrat Muhammad (PBUH). Respect, care, integrity, honesty, and trust should be given priority. They may give special consideration to be vigilant, keeping high canons of moral standards not only in academia but also in society.

\section{References}

Aghenta, J. (1991). Teacher effectiveness in the Nigerian educational system. Edited by BC Emenogu, OVN Okoro et.al Onitsha, Orient Publishers Ltd.

American Psychological Association. (2017). Code of Ethics: General Principles. Washington DC: Author. Retrieved June 16, 2020, from http://www.apa.org/ethics/code/

Barrett, D., Headley, K., Stovall, B. \& Witte, J. (2006). Teacher's perceptions of the frequency and seriousness of violations of ethical standards. The Journal of Psychology, 140(5), 421- 433. doi: 10.3200/JRLP.140.5.421-433

Bishop, W. H. (2013). The role of ethics in 21st-century organizations. Journal of Business Ethics, 118(3), 635-637. doi:10.1007/s10551-013-1618-1

Bowling, A. (2014). Research methods in health: investigating health and health services: McGrawhill Education (UK)

Brok, P. D. (2001). Teaching and student outcomes: A study on teachers' thoughts and actions from an interpersonal and a learning activity perspective. Utrecht: WCC.

Banks, S. (2003). From oaths to rulebooks: a critical examination of codes of ethics for the social professions. European Journal of Social Work, 6(2), 133-144. https://doi.org/10.1080/ 1369145032000144403

Campbell, E. (2003). The ethical teacher: McGraw-Hill Education (UK).

Campbell, E. (2000). Professional ethics in teaching: Towards the development of a code of practice. Cambridge Journal of Education, 30(2), 203-221. https://doi.org/10.1080/0305764 0050075198

Cohen, R. J., \& Swerdlik, M. E. (2010). Psychological testing and assessment: An introduction to tests and measurements. Singapore: McGraw-Hill Companies.

Couch, S. \& Dodd, S. (2005). Doing the right thing: Ethical issues in higher education. Journal of Family and Consumer Sciences, 97(3), 20-27.

Curtis, D. M. (2006). Everything I wanted to know about teaching law school I learned from being a kindergarten teacher: Ethics in the law school classroom. BYU Educ. \& LJ, 455.

Fenwick, T. (2005). Ethical dilemmas of critical management education: Within classrooms and beyond. Management Learning, 36(1), 31-49. https://doi.org/10.1177/1350507605049899

Fraenkel, J. R., \& Wallen, N. E. (2009). How to design and evaluate research in education. New York: McGraw-Hill Companies, Inc.

Freeman, N. K. (2000). Professional ethics: A cornerstone of teachers' pre-service curriculum. Action in Teacher Education, 22(3), 12-18. https://doi.org/10.1080/01626620.2000.10463015

Frisque, D. A., Lin, H. \& Kolb, J. (2004). Preparing professionals to face ethical challenges in today's workplace: Review of the literature, implications for PI, and a proposed research agenda. Performance Improvement Quarterly, 17(2), 28-45. https://doi.org/10.1111/j.19378327.2004.tb00306.x

Gay, L. R., Mills, G. E., \& Airasian, P. W. (2011). Educational research: Competencies for analysis and applications: Pearson Higher Ed.

Glegg, A. (2003). Creating Right-Minded Teachers: British Columbia, 1872-2002. Journal of the International Society for Teacher Education, 7(1), 11-21. https://doi.org/10.1080/ 0022062042000336055

Haider, S. Z., \& Qureshi, A. (2016). Are All Children Equal? Causative Factors of Child Labour in Selected Districts of South Punjab, Pakistan. Journal of New Approaches in Educational Research, 5(1), 3-10. https://doi.org/10.7821/naer.2016.1.132

Haider, S. Z., \& Dilshad, M. (2015). Higher Education and Global Development A Cross-Cultural 
Qualitative Study in Pakistan. Higher Education for the Future, 2(2), 175-193. https://doi.org/10.1177/2347631114558185

Haider, S. Z., \& Hussain, A. (2014). Relationship between Teacher Factors and Student Achievement: A Correlation Study of Secondary Schools. US-China Education Review A, 4(7), 465-480. DOI:10.17265/2161-623X/2014.07A.003

Hertzog, H. S., Pensavelle, M., \& Lemlech, J. K. (2000). Collegial relationships: what does it mean to be a colleague, paper presented at the Annual Meeting of the American Educational Research Association, New Orleans, LA, 24-28.

Husu, J., \& Tirri, K. (2001). Teachers' ethical choices in socio-moral settings. Journal of Moral Education, 30(4), 361-375. https://doi.org/10.1080/03057240120094850

Kelley, P. C., Agle, B. R., \& DeMott, J. (2005). Mapping our progress: Identifying, categorizing, and comparing universities' ethics infrastructures. Journal of Academic Ethics, 3(4), 205-229. https://doi.org/10.1007/s10805-006-9014-4

King, F., \& King, J. (2008). Review of the Victorian Institute of Teaching. Adelaide: Ministry of Education.

Kline, T. J. B. (2005). Psychological testing. Thousand Oaks, CA: Sage Publication.

Krueger, R. A. (1988). Focus groups: A practical guide for applied research. Sage Publication.

Lovat, T. \& McLeod, J. (2006). Fully Professionalized Teacher Education: An Australian study in persistence. Asia-Pacific Journal of Teacher Education, 34(3), 287-300. https://doi.org/ $10.1080 / 13598660600927174$

Margalef, L., \& Pareja Roblin, N. (2016). Unpacking the roles of the facilitator in higher education professional learning communities. Educational Research and Evaluation, 22(3-4), 155-172. DOI: 10.1080/13803611.2016.1247722

Murray, H., Gillese, E., Lennon, M., Mercer, P. \& Robinson, M. (1996). Ethical principles in university teaching. Ontario, Society for Teaching and Learning in Higher Education.

Pelletier, K.L. \& Bligh, M.C. (2006). Rebounding from corruption: Perceptions of ethics program effectiveness in a public sector organization. Journal of Business Ethics 67(4): 359-374. https://doi.org/10.1007/s10551-006-9027-3

Plante, T. G., \& McCreadie, A. (2019). The Santa Clara Ethics Scale. Pastoral Psychology, 68(3), 321329. https://doi.org/10.1007/s11089-019-00861-w

Plante, T. G., \& Plante, L. G. (2016). Graduating with Honor: Best Practices to Promote Ethics Development in College Students. Santa Barbara, CA: Praeger/ABC-CLIO.

Shuell, T. J. (1996). Teaching and learning in a classroom context", in Berliner, D.C. and Calfee, R.C. (Eds), Handbook of Educational Psychology, New York, YK: Macmillan, pp. 726-64.

Smith, W. L., \& Zhang, P. (2009). The academic ethic and the transition to college. College Student Journal, 43(1), 86-98.

Somerville, M. (2000). The Ethical Canary; Science, Society and the Human Spirit, Toronto: Viking, p.284.

Thompson, B. (2003). Understanding reliability and coefficient alpha. Score reliability: Contemporary thinking on reliability issues, 3-23.

Thornberg, R. (2008). The lack of professional knowledge in values education. Teaching and Teacher Education, 24(7), 1791-1798. https://doi.org/10.1016/j.tate.2008.04.004

Vaughn, L. (2015). Beginning ethics: An introduction to moral philosophy: WW Norton.

Walker, J., \& Maddan, S. (2008). Factor analysis, path analysis, and structural equation modeling. Statistics in Criminology and Criminal Justice: Analysis and Interpretation, 3rd ed. USA: Jones \& Bartlett Publishers, 325-351.

Weber, J. (2006). Implementing an organizational ethics program in an academic environment: The challenges and opportunities for the Duquesne University Schools of Business. Journal of Business Ethics, 65(1), 23-42. https://doi.org/10.1007/s10551-005-3970-2

Worthington, R. L., \& Whittaker, T. A. (2006). Scale development research: A content analysis and recommendations for best practices. The Counseling Psychologist, 34(6), 806-838. https://doi.org/10.1177/0011000006288127

Zheng, L., \& Hui, S. (2005). Survey of professional ethics of teachers in institutions of higher education: A case study of an institution in central China. Chinese Education \& Society, 38(5), 88-99. https://doi.org/10.1080/10611932.2005.11031715 